DOI: https://doi.org/10.32839/2304-5809/2021-4-92-64

удК 339.13 .027

Горященко Ю.Г., Бокова Ю.О., Кулешова А.A.

Університет митної справи та фрінансів

\title{
ЧИННИКИ ВПЛИВУ НА РОЗВИТОК ІННОВАЦІЙНО-ІНВЕСТИЦІЙНОЇ ДІЯЛЬНОСТІ СУБ СКТІВ МАЛОГО БІЗНЕСУ
}

Анотація. В статті розглянуто та досліджено чинники впливу на розвиток інноваційно-інвестиційної діяльності суб єктів малого бізнесу. Виявлено те, що подальшого розгляду потребує дослідження інноваційно інвестиційного потенціалу в контексті розробки та реалізації інноваційно інвестиційної стратегії забезпечення стійкого розвитку підприемств. Проблеми визначення ефективності інноваційно-інвестиційного розвитку є вкрай актуальними для економіки України. Вирішення цих проблем і формування працездатної системи показників дозволять оцінити ефективність поточного функціонування інноваційно-інвестиційного механізму і ступінь реалізації поставлених завдань і цілей інноваційного розвитку. Управління інноваційно-інвестиційним розвитком держави відноситься до стратегічно важливих, що пов'язано зі зростанням ролі інновацій та необхідних для цього інвестицій, оскільки вони безпосередньо впливають на основні макроекономічні показники розвитку країни.

Ключові слова: інновації, зовнішньоекономічна діяльність, підприемство.

Goryashchenko Yulia, Bokova Yulia, Kuleshova Anastasia University of Customs and Finance

\section{FACTORS INFLUENCING THE DEVELOPMENT OF INNOVATION AND INVESTMENT ACTIVITIES OF SMALL BUSINESSES}

Summary. Small and medium-sized enterprises play a very important role in economic transformation, for example by helping to create additional jobs and thus equalize unemployment, as well as contributing to local budgets and promoting innovation and economic growth. The article considers and examines the factors influencing the development of innovation and investment activities of small businesses. It is revealed that further consideration requires the study of innovation and investment potential in the context of the development and implementation of an innovation and investment strategy for ensuring sustainable development of enterprises. The necessity of using of innovative sources for investment supply by small enterprises in the course of their business activities is substantiated, classic and innovative sources of financing of innovation and investment activity of small entrepreneurship are differentiated. The need to determine the state of attracting investment and innovation activities in Ukraine, determination of strategic components of development innovation and investment policy and opportunities for their implementation in the state, the need to develop theoretical provisions on the justification of processes formation of an innovation and investment management system, identification of its features in conditions of limited financial resources, development of scientific and methodological provisions and practical recommendations, aimed at improving organizational and economic methods Investment Management determines the relevance of the topic research. Problems of determining the effectiveness of innovation and Investment Management they are extremely relevant for the Ukrainian economy. Solving these problems problems and the formation of a workable system of indicators will allow you to evaluate efficiency of the current functioning of the innovation and investment enterprise mechanism and degree of implementation of the set tasks and goals of the innovation enterprise development. Management of innovation and investment development of the state it is considered strategically important, which is associated with the growth of the role innovations and necessary investments for this purpose, since they directly they affect the main macroeconomic indicators of the country's development.

Keywords: innovation, foreign economic activity, enterprise.

$\Pi$ остановка складному проблеми. $\mathrm{Ha}$ етапі розвитку економіки в Україні виникла об’ективна необхідність в активізації інвестиційної діяльності, бо саме вона є поважною ланкою всієї економічної політики держави, яка забезпечуе стабільне зростання економіки, приріст соціального ефекту, збалансованість макроструктури.

Інвестиційний потенціал підприемства - це здатність господарюючого суб'єкту реалізувати сукупність інвестиційних можливостей щодо генерування додаткових потоків капіталу завдяки мобілізації наявних ресурсів з метою підвищення вартості об'єкту інвестування.

Структура інвестиційного потенціалу підприємства, яка має дуже багато аспектів, обумовлює специфіку побудови системи його оцінки на основі визначених принципів. Базовими положеннями оцінки ефрективності діяльності підприемств щодо залучення та використання інвестиційних ресурсів є застосування комплексного підходу та його інтегрального оцінювання.

На основі більш критичного аналізу існуючих методичних підходів стосовно дослідження складних систем економіки, було розроблено методику інтегральної оцінки інвестиційного потенціалу підприемства на основі співвідношення рівня розвитку потенціалів залучення та відтворення інвестицій.

Актуальність проблеми сучасного стану інноваційно - інвестиційної діяльності розглядаються у роботах таких вчених-економістів: І. Бланк, 
I. Клименко, Ю. Кравченко, В.П. Ляшенко, Л.Ш. Маматова, Г.П. Скляр, Е.В. Скурихина, M.В. Сімонова, та ін. Практично-рекомендаційні аспекти цієї проблеми розглядаються у роботах В. Едельмана, О. Басса, С. Суверова, М. Крейніної, Т. Лепейко, В. Піддубного, В. Савчука, У. Шарпа та ін.

Метою статті $є$ вивчення та систематизація чинників впливу на розвиток інноваційно - інвестиційної діяльності суб єктів малого бізнесу.

Виклад основного матеріалу. У сучасних умовах господарювання інноващійна політика українських підприемств тісно пов'язана з інвестиційною політикою, що спрямована на стимулювання капіталовкладень в інновації промисловості.

Згідно зі статтею 2 Закону України «Про інвестищійну діяльність», інноваційна діяльність як одна із форм інвестиційної діяльності здійснюеться 3 метою впровадження досягнень науково- технічного прогресу у виробництво і соціальну сфреру і передбачає:

- розробку і впровадження нових видів техніки і технології;

- прогресивні міжгалузеві структурні зрушення;

- реалізацію довгострокових науково-технічних програм 3 тривалими строками окупності витрат;

- фрінансування фрундаментальних досліджень для здійснення якісних змін у стані продуктивних сил;

- розробку і впровадження нової, ресурсозберігаючої технології, призначеної для поліпшення соціального і екологічного становища.

Інвестиційна діяльність будь-якого підприемства триває доволі тривалий час та здійснюється через конкретизацію інноваційних напрямків з урахуванням перспективи, тобто формуванням інвестиційної стратегії.

Формування та розробку інвестиційної стратегії підприємства необхідно розглядати як стратегію забезпечення його ресурсної бази для реалізації одного з конкретних варіантів інноваційного розвитку підприемства.

Складність формування інвестиційної стратегії інноващійного розвитку підприемства полягає в тому, що її вибір пов'язаний 3 пошуком оптимального варіанта альтернативних проектів інноваційних рішень, які відповідають меті підприемства і перспективам.

Успіх інноваційної діяльності в значній мірі визначається формами їі організацї та способами фрінансової підтримки [2]. Джерелами фрінансування можуть бути підприемства, фінансовопромислові групи, малий інноваційний бізнес, інвестиційні та інноваційні фонди, органи місцевого управління, приватні особи і т. д. Всі вони беруть участь у господарському процесі і тим або іншим чином сприяють розвитку інноваційної діяльності. У розвинених країнах фрінансування інноващійної діяльності здійснюеться як 3 державних, так і з приватних джерел.

Проаналізувавши структуру фрінансування, можна виділити основні стримуючі фрактори розвитку інновацій промислових підприемств: низький рівень державного фрінансування інноваційного розвитку та недостатність власних коштів підприемств; низька інвестиційна активність вітчизняних, зарубіжних інвесторів; недосконалість податкового законодавства; відсутність мотивації вітчизняних підприемств до впровадження науково-дослідних та дослідно-конструкторських робіт та реалізащії їх результатів; послаблення взаємозв'язків науки та виробництва [1].

Інноваційно-інвестиційний процес в умовах ринкового редормування української економіки може бути проаналізований в контексті загальної економічної ситуащї в Україні. Основою інноваційно-інвестиційного процесу є процес створення та освоєння нової техніки або технології [3].

Невеликим компаніям доручаються величезні можливості для більш глибокої спеціалізації, в сучасних умовах вони є невід'ємними складовими великого виробництва, що забезпечують підвищення його едеективності. Як правило, малий бізнес спеціалізується на пошуку та розробці нових технологічних ідей. В основному тому, що це найдешевший процес впровадження інновацій та їх доставки споживачам. Більше того, малі підприемства часто виступають експериментаторами інновацій, на які передається ризик на ранній стадії розробки нових продуктів або технологій, що використовуються [5].

Для малого бізнесу характерні: обмежений доступ до фінансових ринків, високий рівень гнучкості в підприемницькій діяльності, орієнтація на постійне вдосконалення власної діяльності 3 акцентом на місцеві ресурси, наявність двостороннього спілкування між підприемцем та його клієнтами та роль фрактора, що створює ринок. Малий бізнес - це особливий тип економічної поведінки, предметом якого є дві основні узагальнюючі якості - поєднання власника і начальника компанії в одній особі та підвищений рівень економічного ризику на всіх стадіях господарської діяльності [3].

Прийняття Українського земельного кодексу відкрило широкі можливості для розвитку підприемництва в агропромисловому виробництві, заснованому на власності на землю як засобі виробництва, оскільки земля є основним засобом виробництва в сільському господарстві. Однак раціональне використання землі $е$ запорукою успішного фрункціонування малого бізнесу в Україні. Інноваційна модель розвитку земель базуеться на використанні добрив та різних хімічних речовин, тобто вона зосереджена на інтенсивному землекористуванні. Однак це небезпечно і призводить до різних патологій людини. Конкурентоспроможність українського села залежить не від кількості виробленої продукції, а від їі якості. Основними показниками добробуту $€$ середній клас, рівень життя населення середнього класу, а малий бізнес є формою підприемництва середнього класу.

Ферми, що спеціалізуються на виробнищтві 2-3 видів продукції, що потребує додаткової переробки, не можуть забезпечити високий прибуток. Тому малий бізнес повинен продемонструвати гнучкість, динаміку, власні маркетингові дані, вплив ринку, швидку реструктуризацію та редизайн [4].

Кількість малих підприемств, які займаються інноваційною діяльністю, постійно зростае. Зростає і питома вага в загальній кількості малих підприемств.Інвестиційні та інноваційні процеси слід розглядати не окремо, а у комплексі, що дозволяє стверджувати про необхідність реалізації інвести- 


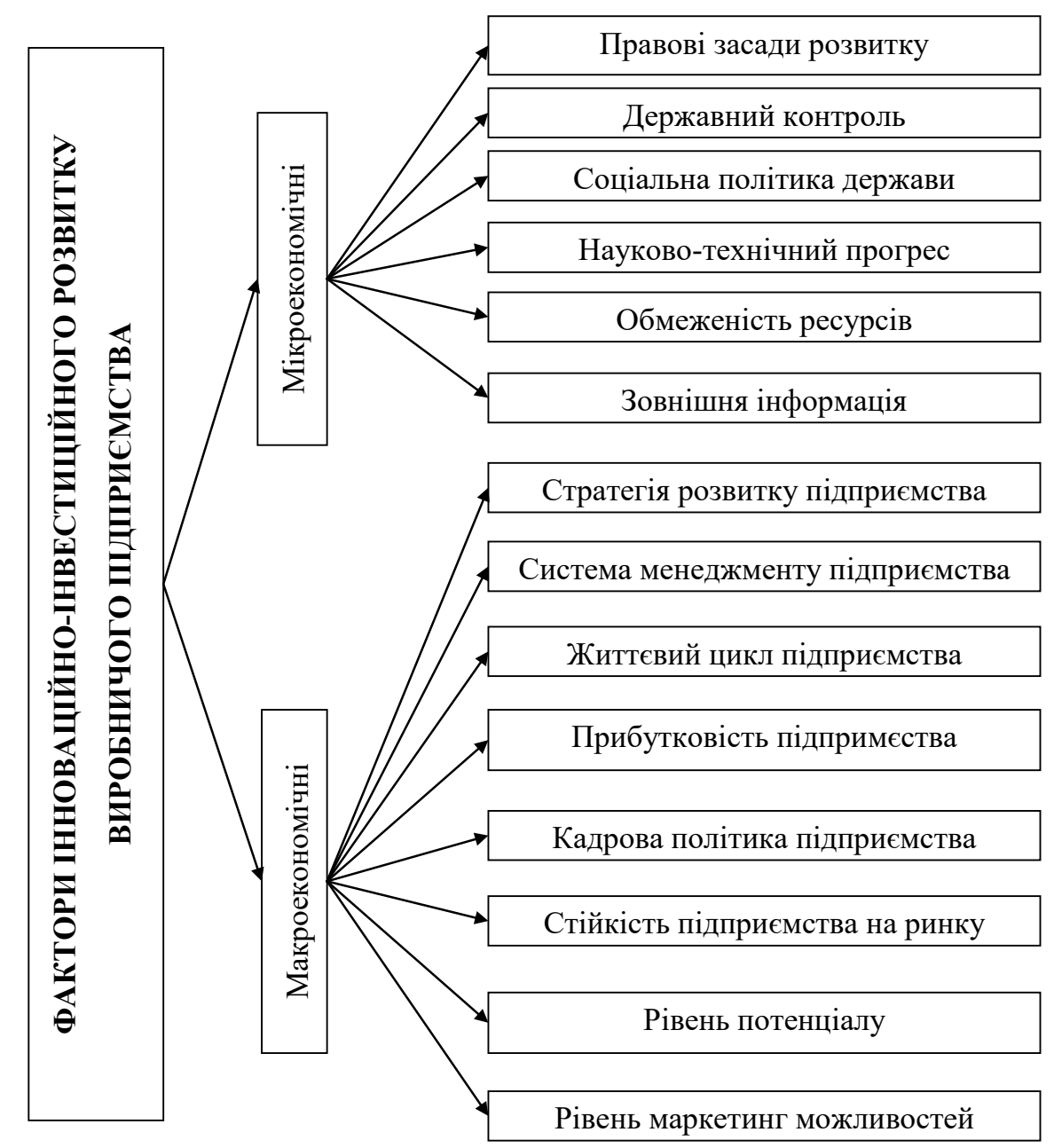

Рис. 1. Ключові фактори інноваційно-інвестиційного розвитку виробничого підприемства як складової його конкурентоспроможності в системі маркетингу

Джерело: систематизовано за [1]

ційно-інноваційної стратегї забезпечення сталого розвитку, яка складається з двох взаємопов'язаних та взаємовпливаючих блоків: інвестиційного та інноваційного, об'єднаних єдиною системою принципів, методів та механізмів реалізацї, критеріїв прийняття управлінських рішень [2].

Тіньова економічна діяльність негативно позначається на рівні інноваційного розвитку, що позначається на якості розвитку сектора МП, який без інновацій стає неконкурентоспроможним щодо решти суб'єктів господарювання. У цій ситуації малі підприемства змушені змінювати свою діяльність у секторі тіньової економіки, що впливає на рівень економічної безпеки країни, як внутрішню загрозу в умовах зниження ВВП, збільшуючи частку "прихованої заробітної плати", а отже рівень життя населення.

Економічна діяльність тіні має багато негативних наслідків, що впливають на інноваційну діяльність та інвестиційну привабливість державної економіки в цілому та її модернізацію на основі інтенсивного шляху розвитку.

Найважливіші з них такі [3]:

- неправильна оцінка рівня та масштабу тіні економічної діяльності може призвести до прийняття неправильних інвестиційних рішень на різних етапах державної влади, помилок у роз- рахунку важливих соціально-економічних показників розвитку компанії та зниження рівня інвестиційної привабливості території;

- як результат, збільшуеться податковий тягар, зростає податковий тягар в офіційному секторі економіки, зменшуеться інноваційна діяльність та інвестиційна привабливість, об'єкти потрапляють у неформальний сектор, підвищується рівень тіньової економічної діяльності;

- через корупцію як основну складову тіні економічної діяльності та контролю тіньових процесів виникає невідповідність між перерозподілом сектору економіки, перерозподілом внутрішніх доходів серед обмеженого кола людей, а отже і зниженням інноваційна діяльність;

- існуе різкий пакет суспільства, недовіра до влади, посилення диференціації між дуже багатими та дуже слабкими, збільшення кількості громадян, які живуть поза межею або на межі бідності;

- спостерігається зростання неконтрольованої торгівлі товарами та послугами неналежної якості: товарами, що становлять небезпеку для життя та здоров'я громадян, i, як наслідок, зниження інноваційної та інвестиційної привабливості регіону;

- наростаюча нелегальна міграція, міграційна політика та боротьба 3 державним безробіттям стають неефективними. 
Беручи до уваги економічну безпеку суб'ектів господарювання, слід зазначити, що в економічній літературі загалом це зрозуміло: «... здатність суб'єктів господарювання надійно виконувати свої функції, забезпечуючи реалізацію економічних інтересів та розвиток бізнесу» [5].

Малі та середні підприемства мають велике значення для української економіки. Малий бізнес у своїй діяльності характеризуеться гнучкістю та високою пристосованістю до зовнішніх впливів. Безпека господарської діяльності малих піпприемств підвищуе рівень економічної безпеки території i, в свою чергу, призводить до зростання соціально-економічного розвитку регіону та країни в цілому.

Очевидно, головний фактор інноваційної діяльності малого бізнесу $є$ кінцевий результат економічна ефрективність. Усі інновації є кінцевою метою підвищення соціально-економічної ефективності виробництва та результатів інновацій діяльність залежить від ефективності внеску інновацій в інновації, стабільності бізнес сьогодні і майбутній успіх.

Створення соціально орієнтованої економічної моделі України можливе лише за умови умови для інтенсивного розвитку підприемництва [3]. Таким чином активізуеться розвиток підприемництва структурна перебудова економіки та забезпечуе велику свободу вибору та створення ринку додаткова робота. У той же час, швидке відшкодування витрат та своєчасність реагування на зміни споживчого попиту [3]. Підприемництво допомагає забезпечити ринок товарів та послуг, сприяе розвитку конкуренщії, впровадженню науковотехнічних досягнень та збільшенню експортного потенціалу національної економіки.

Отже, розвинена ринкова економіка базуеться на оптимальному поеднанні великого корпоративний та малий бізнес. Функціонування різ- них незначних форм в економіці бізнес дозволяе реалізувати самі принципи конкуренції та свободи підприемництва.

Важливим позитивним фактором для малого бізнесу є те, що вони заповнюють ці ніші економіки, вони не зацікавлені у великих корпораціях, в яких вони не можуть використовувати свої вигоди від організації великого виробництва. Перш за все, сорери, які користуються попитом.

Персоналізовані «персоналізовані» нефінансовані товари та послуги споживач. Такі ринкові ніші займають невеликі компанії з більш гнучким управлінням та меншою кількістю масивна конструкція.

Для малого бізнесу конкурентне середовище - це інституційне середовище.

Малий бізнес іноді бере кредити, забезпечуючи насичення ринків товарами та послугами мають монопольне становище. Як правило, це коли вони доречні адміністративні бар'ери [2].

Малий бізнес досить динамічний у порівнянні 3 великими корпораціями перебудовуеться i peaгуе на зміни ринку. Бути ближче до споживача, він краще відчуває свої інтереси і здатний їх задовольнити. Але ці переваги потенційні.

Вони проявляються лише за умови належного управління, їх потрібно постійно впроваджувати і підтвердити в конкурсі [2]. Розвиток франшизи також доводить ефективність малого бізнесу. малий бізнес продавати продукцію великих корпорацій, використовуючи торгові марки товарний знак останнього. Ця форма практично поширена в розвинених країнах надає малому бізнесу друге дихання.

Слід зазначити, що в ході економічних реформ, проведених у країнах СНД та у Східній Європі розвиток малого бізнесу став важливим фрактором створення конкурентоспроможності навколишнього середовища, сприяло загально-

Таблиця 1

Порівняльна характеристика обраних методів обрахунку економічної ефективності проектів

\begin{tabular}{|c|c|c|}
\hline Переваги методу & Недоліки методу & Сфера застосування \\
\hline \multicolumn{3}{|c|}{ Метод чистої приведеної вартості } \\
\hline $\begin{array}{l}\text { Метод орієнтований на } \\
\text { досягнення головної } \\
\text { мети фінансового } \\
\text { менеджменту - збільшення } \\
\text { надбання акціонерів. }\end{array}$ & $\begin{array}{l}\text { Метод не об'єктивно відображає } \\
\text { вплив зміни вартості нерухомості } \\
\text { та сировини на чисту поточну } \\
\text { вартість проекту. Використання } \\
\text { методу ускладнюється труднощами } \\
\text { прогнозування ставки дисконтування. }\end{array}$ & $\begin{array}{l}\text { При схваленні або відмови від } \\
\text { єдиного проекту, а також при } \\
\text { виборі між декількома проектами } \\
\text { застосовується даний метод, } \\
\text { рівноцінний методу внутрішньої } \\
\text { ставки рентабельності. }\end{array}$ \\
\hline \multicolumn{3}{|c|}{ Метод внутрішньої норми дохідності } \\
\hline $\begin{array}{l}\text { Достовірність розрахунків } \\
\text { дозволяє ощінити } \\
\text { прибутковість проекту }\end{array}$ & $\begin{array}{l}\text { Метод не вирішує проблему } \\
\text { множинності внутрішньої ставки } \\
\text { рентабельності. }\end{array}$ & Аналогічно із попереднім. \\
\hline \multicolumn{3}{|c|}{ Метод дисконтованого періоду окупності } \\
\hline $\begin{array}{l}\text { Враховуеться концепція } \\
\text { грошових потоків і можливість } \\
\text { реінвестування доходів } \\
\end{array}$ & $\begin{array}{l}\text { Метод не враховує грошові } \\
\text { надходження після закінчення } \\
\text { терміну окупності проекту }\end{array}$ & $\begin{array}{l}\text { Метод застосовуються для швидкої } \\
\text { відбору проектів, а також в умовах } \\
\text { індляції, політичної нестабільності }\end{array}$ \\
\hline \multicolumn{3}{|c|}{ Метод індексу прибутковості } \\
\hline $\begin{array}{l}\text { Простота розрахунків дозволяє } \\
\text { легко оцінити прибутковість } \\
\text { проекту }\end{array}$ & $\begin{array}{l}\text { Не враховуються доходи від } \\
\text { ліквідації старих активів, можливість } \\
\text { реінвестування отриманих доходів. }\end{array}$ & $\begin{array}{l}\text { Метод не дозволяє вибрати проект з } \\
\text { однаковими нормами прибутку, але } \\
\text { різними інвестиційними витрати } \\
\text { Використовується під час прийняття } \\
\text { рішення про доцільність подальшого } \\
\text { аналізу або відмови від проекту на } \\
\text { ранній стадії }\end{array}$ \\
\hline
\end{tabular}

Джерело: доповнено за [4] 
му відновленню економіки. Однак у контексті ринкової трансформації

Ряд особливостей економіки в перехідний період сильно впливає на малий бізнес. Між ними:

- структурні диспропорції в економіці, що перешкоджають розвитку підприемництва;

- недостатній розвиток ринкової інфраструктури та недосконалість законодавства база, уповільнюе процес відкриття малого бізнесу;

- низький рівень управління в багатьох країнах і приватизований підприемства;

- неедективна робота державного апарату, недоліки в законодавчій базі, високі податки затінюють значну частину економічної діяльності.

Також, згідно із Наказом Міністерства економічного розвитку та торгівлі України № 1279 від 13.11.2012 р. «Про затвердження методичних рекомендацій 3 розроблення інвестиційного проекту, для реалізації якого може надаватися державна підтримка» та Постановою Кабінету Міністрів України № 684 від 12.07.2012 р. «Порядок та критерії оцінки економічної ефективності проектних (інвестиційних) пропозицій та інвестиційних проектів», визначено, що оцінка економічної едективності інвестиційної пропозиції, інвестиційного проекту здійснюеться за такими критеріями:

- чиста приведена вартість;

- внутрішня норма дохідності;

- дисконтований період окупності;

- індекс прибутковості.

Залежно від підприємства, реалізація інноваційного проекту можлива двома способами [4]:

1. Реалізація проекту діючим підприемством, що випускає різні види продукції. Вихідний (на момент проведення розрахунків) баланс підприемства відображає структуру й вартість власних i позикових коштів підприємства, виражену в показнику WACC (середньозважена вартість капіталу).

Tоді: NPV проекту = NPV підприемства із проектом - NPV підприемства без проекту.

Розрахунки потоків для визначення NPV можуть проводитися [2]:

а) без обліку джерел додаткового фінансування, які будуть потрібні для реалізащії проекту: розраховуеться FCF з урахуванням повернення отриманих раніше позикових коштів і відсотків за ними; як ставка дисконтування використовується показник WACC підприемства (тому що реалізація проекту не повинна приводити до росту вартості капіталу компаніі).

Показник NPV, що розраховуеться, за суттю відображає оцінку ринкової вартості бізнесу підприемства (із проектом і без нього), проведену iз застосуванням підходу, заснованого на прогнозуванні витрат і прибутків, які генеруються об'єктом оцінки у майбутньому.

б) 3 урахуванням додаткових джерел фрінансування, необхідних для реалізації проекту: до складових потоку FCF додаються одержувані підприемством у прогнозний період додаткові власні й позикові кошти, і віднімаеться повернення позикових коштів і плата за їхне використання.

Цей потік характеризуватиме грошовий потік, що залишається в розпорядженні акціонерів; ставка дисконтування повинна бути не нижчою за досягнутий рівень ROE підприємства.
Показник NPV, що розраховуеться, відображає ринкову вартість акціонерного капіталу підприемства.

2. Реалізація проекту за схемою проектного фінансування зі створенням спеціальної проектної компанії Special Purpose Vehicle (SPV), засновниками якої можуть бути різні зацікавлені в проекті організації й підприемства:

a) розрахунки на етапі створення проектної компанії. Без обліку джерел фрінансування: початковий баланс нульовий; грошовий потік FCF; ставка дисконтування та сама, що й при розрахунку ефрективності проекту загалом. Показник NPV, що розраховується, відображае вартість проекту (бізнесу, пов'язаного з його реалізацією).

3 урахуванням джерел фінансування: початковий баланс нульовий; грошовий потік - FCFE; ставка дисконтування не нижча за досягнутий рівень ROE підприемств тієї самої галузі. Показник NPV, що розраховується, відображає вартість акціонерного капіталу проектної компанії.

б) проект $\mathrm{T}$ років реалізуеться проектною компанією (на момент проведення розрахунків баланс проектної компанії відображає їі активи й пасиви та враховує особливості всіх джерел фрінансування, використаних за Т років).

Без обліку джерел додаткового фінансування [2]:

- грошовий потік не враховуе надходження й повернення додаткових позикових ресурсів та їхню платність (FCF);

- ставка дисконтування використовуеться WACC підприемства.

Розрахунок NPV відображає вартість бізнесу проектної компанії без обліку додаткового фінансування.

3 урахуванням джерел додаткового фрінансування: грошовий потік враховуе надходження й повернення як існуючих на момент Т, так і додаткових позикових ресурсів і їхню платність (FCFE); ставка дисконтування не нижча за досягнутий рівень ROE галузі [2].

Розрахунок NPV відображає вартість акціонерного капіталу проектної компанії 3 обліком додаткового фрінансування. Постановка задачі оцінки едективності участі в проекті кредитора передбачає звернення основної уваги на таке.

Доцільність кредитування банком підприемства, що реалізує проект, визначається позитивною величиною NPV потоку, у якому відтоками $\epsilon$ кошти, надані банком за кредитною лінією (або кредитом), а притоками - повернення кредитних ресурсів разом з відсотками.

Висновки. Таким чином, оцінювання ефективності інноваційно-інвестиційної діяльності підприемств обов'язково має базуватись на загальноприйнятих показниках інвестиційного проекту, а також побудові сценарного підходу. На основі узагальнених положень теорії інвестування сформовано деякі положення щодо етапів формування та реалізацї інноваційно-інвестиційної стратегії розвитку промислових підприемств, які враховують принщипи проблемно-орієнтованого підходу та надають можливість реалізувати стратегічні плани в умовах динамічного коливання виробничо-економічної системи. Подальшого дослідження в цьому напрямі потребує дослідження інноваційно-інвестиційного потенціалу в контексті розробки та реалізащї інноваційно-інвестиційної стратегї забезпечення стійкого розвитку підприємств. 


\section{Список літератури:}

1. Маматова Л.Ш. Сучасний стан фрінансово-інвестиційного потенціалу України. Еконолічні науки. Зб. наук. пр. Маріуполь : ДВНЗ «ПДТУ», 2015. Вип. 29. С. 172-180.

2. Маматова Л.Ш. Сущность и методы разработки стратегии обеспечения фринансово-инвестиционного потенциала промышленных предприятий. Scientific Letters of Academic Society of Michal Baludansky - UK TU Košice, Slovakia. 2015. № 5. Vol. 3. Pp. 150-154.

3. Маматова Л.Ш. Фінансово-інвестиційний потенціал підприемства: сутність та структура. Университетская наука-2016. Международная науч.-техн. конф. (Мариуполь, 19-20 мая 2016 г.). Мариуполь : ГВУЗ «ПГТУ», 2016. T. 3. C. 8.

4. Сімонова М.В. Оцінка інвестиційної привабливості України на основі аналізу методик, розроблених провідними міжнародними організаціями. Вісн. Житол. держ. технолог. ун-ту. Серія : Еконолічні науки. 2012. № 1(59). C. 283-287.

5. Скляр Г.П. Економічні умови і протиріччя розвитку споживчої кооперації в перехідній економіці : монографія. Г.П. Скляр. Полтава : РВВ ПУСКУ, 2018. 279 с.

6. Скоробагата Л.В., Шевчук В.О. За наук. ред. чл.-кор. НАН України О. Г. Осауленка. Держкомстат України, 2015. 282 c.

7. Скурихина Е.В. Инвестиционно-инновационный потенциал региона: сущность, содержание, фракторы состояния и развития. Молодой ученыцй. 2012. № 3. С. 192-195.

8. Фомин П.А Особенности оценки производственного потенциала промышленных предприятий: Библиотека экономиста: бізнес-планирование, бюджет. URL: www.cis2000.ru/1/37_1_1.shtml-81k

\section{References:}

1. Mamatova L.S. (2015) Townhouse with renovated mill finansovo-investitsionnogo potential of Ukraine. Visnyk Priazovskogo sovereign technonogy University. Series: Economcs science: ZB. Sciences. St. Mariupol: SU "PDU", vol. 29 , pp. $172-180$.

2. Mamatova L.S. (2015) The Nature and methods of strategy development of financial and investment potential of industrial enterprises. Scientific Letters of Academic Society of Michal Baludansky - UK TU Košice, Slovakia, no. 5 , vol. 3 , pp. $150-154$.

3. Mamatova L.Sh. (2016) Finansovo-investitsiyniy potentsialpidpriemstva: sutnist ta struktura. University Science-2016: International Scientific and Technical Conference. conf. Mariupol: GVUZ "PSTU", vol. 3, p. 8.

4. Simonova M.V. (2012) Otsinka investitsiynoy privablivosti Ukrainy na osnovi analizu metodik, rozroblenikh providnimi mizhnarodnimi organizatsiyami. Visnik Zhytomyr derzhavnogo tekhnologichnogo universitetu, no. 1(59), pp. 283-287.

5. Sklyar G.P. (2018) Ekonomichni umovi i protirichcha rozvitku spozhivchoi cooperatsii v perekhidnii ekonomitsii: monografiya. Poltava: RVV PUSKU, 279 p.

6. Skorobagata L.V., Shevchuk V.O. (2015) / za nauk. ed. chl.-kor. NAS of Ukraine O.G. Osaulenka. Derzhkomstat of Ukraine, $282 \mathrm{p}$.

7. Skurikhina E.V. (2012) Investment and innovation potential of the region: essence, content, factors of state and development. Young scientist, no. 3, pp. 192-195.

8. Fomin P.A., Starovoitov M.K. (2000) Features of assessing the production potential of industrial enterprises: The economist's library: business planning, budget. Available at: www.cis2000.ru/1/37_1_1.shtml-81k 